\begin{tabular}{l|l}
$\mathbf{m}$ & south \\
asia
\end{tabular}

samaj multidisciplinary

ui!'u

journat
South Asia Multidisciplinary Academic Journal

6 | 2012

Revisiting Space and Place: South Asian Migrations in Perspective

\title{
Overseas Temples and Tamil Migratory Space
}

Pierre-Yves Trouillet

\section{(2) OpenEdition \\ Journals}

Electronic version

URL: http://journals.openedition.org/samaj/3415

DOI: 10.4000/samaj.3415

ISSN: $1960-6060$

Publisher

Association pour la recherche sur l'Asie du Sud (ARAS)

\section{Electronic reference}

Pierre-Yves Trouillet, « Overseas Temples and Tamil Migratory Space », South Asia Multidisciplinary Academic Journal [Online], 6| 2012, Online since 28 December 2012, connection on 01 May 2019.

URL : http://journals.openedition.org/samaj/3415 ; DOI : 10.4000/samaj.3415

This text was automatically generated on 1 May 2019.

\section{(c) (i) (3) $\Theta$}

This work is licensed under a Creative Commons Attribution-NonCommercial-NoDerivatives 4.0 International License. 


\title{
Overseas Temples and Tamil Migratory Space
}

\author{
Pierre-Yves Trouillet
}

1 The great 'Arulmigu Tirumurugan Temple' in Montreal (Figure 1), whose construction was completed in 2006, is one of the numerous temples built by Tamil Hindu migrants not only in Canada but throughout the world ${ }^{1}$. Thousands of miles away, for instance, more than a hundred Tamil temples of various sizes have been erected in Mauritius since the 18 th century (Sooriamoorthy 1989), and the buildings of the largest ones, like the one in Montreal, have grown considerably over the past decade. ${ }^{2}$

2 These two examples are no exception, yet they are indicative of the exportation of Tamil temples on a global scale (Punzo-Waghorne 2004). The traditional anchorage of Hinduism in South Asia (Eck 1998) and the fact that the five continents are now concerned by this exported form of Hinduism prompt us to ponder the relations that exist between these overseas temples, their holy land of origin and the transnational Tamil community. 
Figure 1. The Montreal Arulmigu Tirumurugañ Temple and its gōpuram

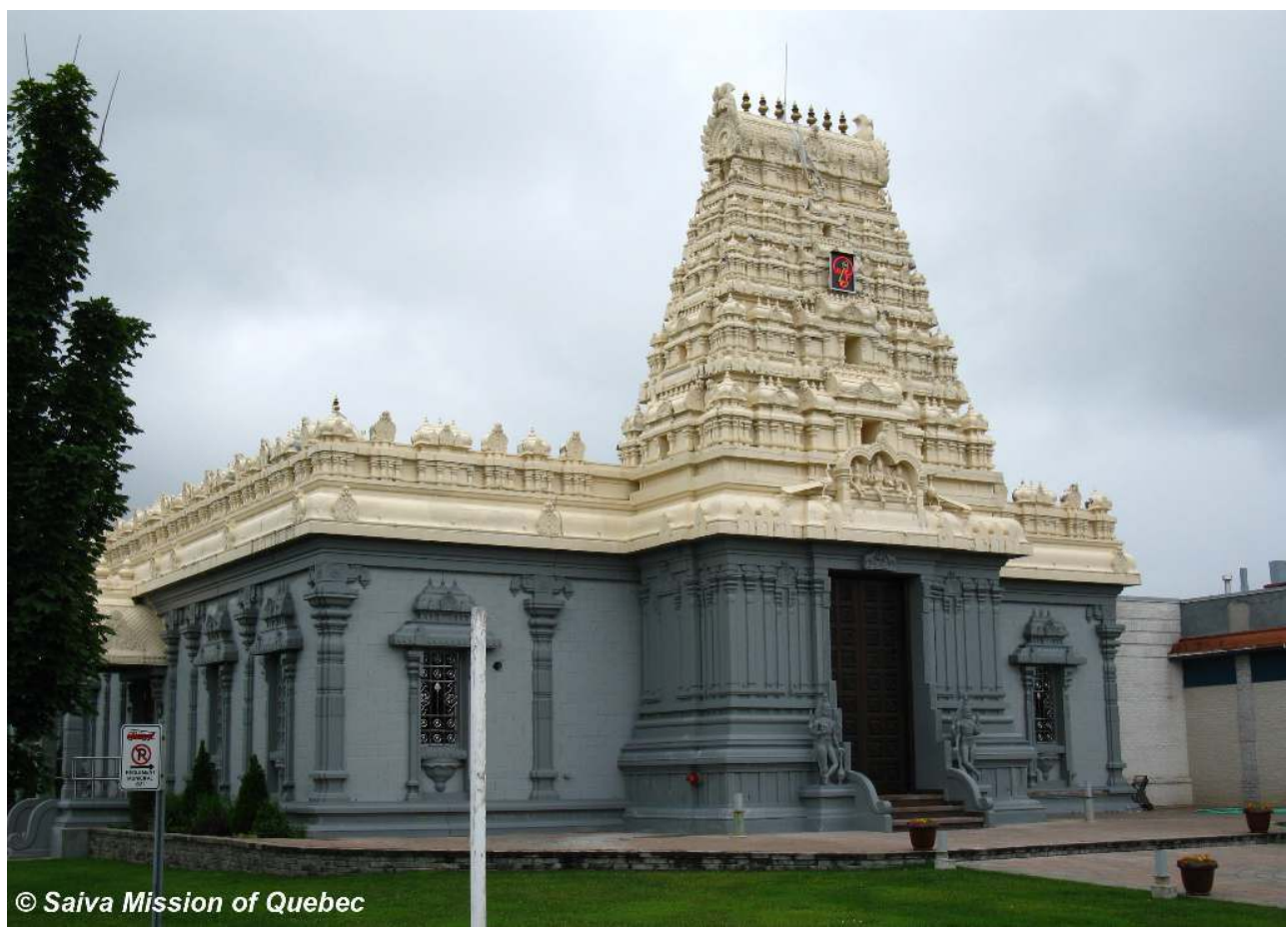

This contribution focuses on identity stakes as well as the spatial meanings and transnational connections related to the making of such places. In addition, the different kinds of relationships linking overseas Tamil temples and the spaces interconnecting Tamil migrants worldwide are addressed. The study of the history, the characteristics and the issues related to some of these places in Canada and Mauritius helps to both fully identify the processes by which Tamil temples have become major centres of transnational social spaces and to document the geographical features associated with the building of places by migrant communities in host countries.

\section{Framework, issues and method}

\section{The Tamil temple as a haut lieu}

4 Temples (kōvil or kōyil $\left.\left.\right|^{3}\right)$ have been places of major importance for Tamil societies for more than fifteen centuries (Appadurai 1981, Dayalan 1992). They are not only holy places presided over by one or more deities (kațavul, têvatai or teyvam), but social, community, economic and political poles, whose areas of influence are more or less far-reaching. Indeed, Tamil temples come in many different sizes, ranging from a simple altar to a vast pilgrimage centre, and host local, regional or pan-Hindu deities. These temple deities often ensure the function of protecting families, villages, castes or larger communities based on an ethno-linguistic or sectarian sense of belonging. The different communities gather at the temple on a regular basis not only to honour their divinity and to receive the 'vision' (darśana) of it, but also very often to consecrate their social unity and their internal hierarchy by performing rituals. Indeed, for centuries, the Tamil temple has been regarded as a stage, i.e. a 'symbolic space' (Appadurai 2008: 18-19) where social statuses are publicly displayed and sometimes challenged. 
Tamil temples are 'places' in the full sense of the meaning that geographers give to them. Indeed, by influencing population displacements-the pilgrimage being the best example - , they polarize spaces, cancel out distances, place subjects and objects in a position to interact, thus facilitating encounters or at least a co-presence. Like any other place, these temples are also micro-spaces for existential and social experiences, both individual as well as collective. But with regards their ritual, religious, political (and sometimes economic) functions, Tamil temples appear to be more specifically and historically 'hauts lieux'. ${ }^{4}$ This kind of meaningful place includes 'sites of memory' (Nora 1984-1992) with their nationalist and commemorative resonance, yet they should not merely be reduced to this. The advances made in this field by French social and cultural geography, with the focus on the social, cultural and existential meanings of places, has demonstrated that hauts lieux do indeed have a patrimonial value, but that they also 'express symbolically, through their representations and their uses, a collective value system' (Debarbieux 2003: 448), just as the Tamil temple does.

6 It is also worthwhile considering Tamil temples as hauts lieux because of the importance of the spatial dimension of social facts as recognized in social science (Soja 1984). For Michel Foucault, for instance, 'the present epoch will perhaps be above all the epoch of space, (...) one [epoch] in which space takes for us the form of relations among sites' (1986: 22-23). This question of the relationships between places not only concerns the diasporic phenomena but also Tamil temples, which are now present on the five continents under the cumulative effects of the international migrations of Tamilians (Guilmoto 1991), the establishment of a 'Tamil diaspora' (Clothey 2006, Fuglerud 1999, Goreau-Ponceaud 2011, Miller et al. 2010, Ranganathan 2011) and the perpetuation of their tradition of temple builders ${ }^{5}$ overseas.

\section{The Tamil diaspora}

7 Indeed, overseas Tamil communities constitute a 'diaspora' according to the definition proposed by Robin Cohen (1997), who considers the diaspora as a geographically dispersed group, but whose members maintain mutual contact. The World Tamil Confederation is a good example of how relationships are maintained between Tamils scattered over the world. Founded in 1999 in Chennai, South India, the organization's objectives are to 'protect the physical welfare of Tamils, the cultural identity of Tamils, and the civic, political and human rights of Tamils' ${ }^{6}$ It even has its own national symbols, including an anthem and a flag, reflecting the will of its activists to unite Tamils of all over the world around what might be called a 'transnation'.?

8 Nevertheless, the Tamil diaspora should not be regarded as a homogeneous entity, notably because the worldwide dispersal of Tamils originates from two neighbouring territories (Figure 2): on the one hand, Tamil country in South India, which is the Tamils' historic home (the Tamilakam, i.e. the 'Tamil homeland') and which in 1969 became one of the Federated States of the Republic of India under the name of Tamil Nadu ('Tamil country'). And on the other hand, Northern Sri Lanka, where the first Tamils from India settled during the $1^{\text {st }}$ century $\mathrm{AD}$ and who are the original members of the 'Tamils of Jaffna' ethnic group, as opposed to other Tamil immigrants who settled in the middle of the island in the nineteenth century to work on colonial plantations (Guilmoto 1987). 
Figure 2. Locations of Tamil speaking areas in India and Sri Lanka

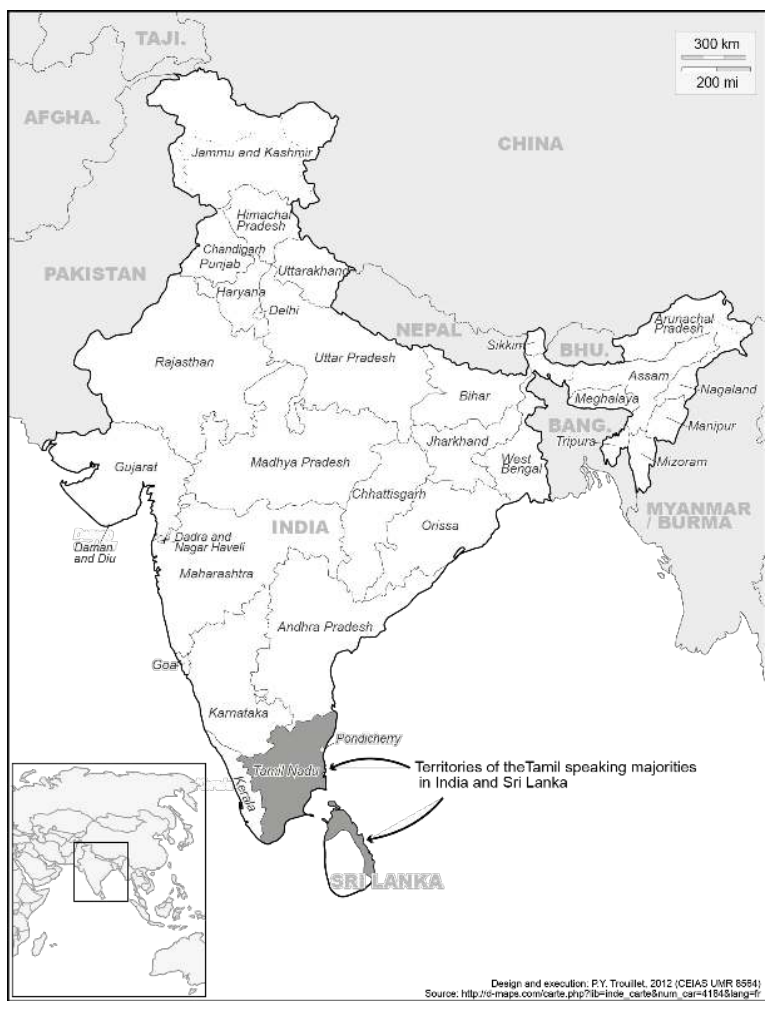

Indeed, during British rule many Tamils from India migrated to South East Asia, the Caribbean and Africa as well as the Mascarene Islands, mainly as migrant workers (coolies) on contract under the indenture system or as employees of the colonial administration. Today, it is mainly the upper middle class that migrates, choosing to settle in the West, and more or less skilled workers that go to spend a few years in the Gulf States or on the Malaysian Peninsula.

The migration of Sri Lankan Tamils is generally more recent and of a different nature. It consists mainly in refugees fleeing the civil war which, from 1983 to 2009, opposed the Buddhist Sinhalese majority to the Liberation Tigers of Tamil Eelam (LTTE), a separatist group fighting for the creation of an independent Tamil State (Eelam or İlam) in the North of the country (Dequirez et al. 2011, Meyer 2001). These political migrants sought refuge mainly in Tamil Nadu and in the West.

Despite some non-negligible differences in identity (ibid.) and the fact that they have sometimes remained two distinct groups, such as in Paris (Goreau-Ponceaud 2011), Tamil communities of India and Sri Lanka share essential values, such as language (even if they do not speak exactly the same Tamil), culture and religion, which have enabled them to develop a diasporic consciousness.

\section{Objective, reasoning and method}

The Tamil diaspora has not escaped the cultural, social and spatial consequences of globalization (Appadurai 1996). It is in this context of a 'globalised world' that the transnationalization of Tamil Hinduism has developed. In addition to the multiplication of temples around the world, it is characterized by numerous exchanges and the 
circulation of many goods and people between South India, Sri Lanka and the diaspora countries, which fit into 'transnational social fields' (Basch et al. 1994), i.e. spaces of sociability created by a criss-cross of cultural, economic, political and religious links across many nation-states.

Several reference studies have already dealt with overseas Hinduism, whether it is considered to be 'Creole' (Benoist 1998, Claveyrolas 2010) or 'diasporic' (Clothey 2006, Jaffrelot \& Therwath 2007, Rukmani 2001, Vertovec 2000), yet none has focused on the material and symbolic links that overseas temples maintain with each other, and with the different spaces of the diaspora. This contribution sets out to study the relationships between these temples and all the places and spaces connected by Tamil migrations that Gildas Simon (2008) calls 'migratory space'.

It is legitimate to reflect on whether temples have become part of transnational social spaces, especially since religion allows migrants and their descendants to preserve their cultural and identity markers despite their displacement, and to maintain physical and symbolic links with their home countries and other dispersed communities. During the migration process or in the diaspora, solidarity between coreligionists may prove reassuring when faced with the ordeals of exile and the feeling of being uprooted. Religion provides the bond of mutual belonging and can restore the coherence of a collective history (Bordes-Benayou 2009). Thus religion may help to find an ethnic identity based on an ancestral and historic tradition (ibid.), even if it sometimes means reinventing it. The importation of objects of worship, the transposition of rituals and the reproduction of practices or of holy places are sometimes regarded as necessary in order to preserve an identity. They ensure that a link is maintained with the territory of origin, which remains the reference in terms of religious and cultural 'authenticity' (Bradley \& Trouillet 2011). Mimetism towards the land of origin expresses a desire to extend any original religious practices in order to offset the effects of a diluted identity experienced from afar. Collective religious activities tend to be increasingly displayed in the public space (Jacobsen 2008) and may provide migrant communities with a structural framework. The main spatial features of these activities are the organization of processions and the (re)construction of places of worship, where the slightest gestures and manners are reproduced.

These properties of religion and the quality of the Tamil temple as a haut lieu prompt us to ponder the existence of significant links between temples and transnational spaces of the Tamil diaspora. Due to the diversity of this transnational community, we had to study different territorial contexts invested by it in order to test the above hypothesis. As suggested in the introduction, two complementary case studies were chosen. The first is Mauritius, where the Tamil presence dates from the colonial period and originates mainly from South India. The second case concerns Canada and is characterized by contemporary Tamil immigration that is overwhelmingly of Sri Lankan origin. Each of these two contexts was the subject of a field study in 2008, according to an essentially qualitative methodology based on interviews and observations carried out in situ. The first survey, over a period of two weeks, aimed at reconstructing the genesis of the first Hindu temple built by an exclusively Tamil community in Montreal. The second lasted three months and focused more generally on Tamil Hinduism as practised and experienced in Mauritius. These two studies-one based on the recent building of a Sri Lankan Tamil temple in a country of the 'Global North', the other on a set of temples that have been territorialized over time by Tamils of South India on a Creole Island-provide 
different forms of possible relationships between the overseas Tamil temple and the Tamil migratory space. A first set of relationships concerns the realm of identity and politics, while a second set refers to transnational flows and spatial rhetoric.

\section{Hauts lieux of identity and politics}

16 Whether in the home country or in the diaspora, the Tamil temple corresponds to what Joël Bonnemaison (1981: 256) called a 'geosymbol', i.e. a space 'that in the eyes of the people and groups takes on a symbolic and cultural dimension, where their values are rooted and their identity reinforced'. Geosymbols may be places, like the hauts lieux, but also itineraries or territories. Reference to the definition of this other concept helps to specify the properties of hauts lieux, notably with regard to identity and territorial issues. Indeed, in the Tamil migratory space, the temple is not only a place of identity differentiation and of adhesion to common values, but also a landmark representing the territorialization of identity and the expression of political issues. To understand the foundations, the stakes involved and the modalities of these processes, the three main parts of the migratory space-countries of origin, host countries and diaspora community -have to be taken into account.

After showing how overseas temples are markers of Tamil identity in the host countries, I discuss the transnational construction of the Tamil diasporic identity that crystallizes around these temples. I subsequently evoke how these places may eventually become involved in political issues on different scales.

\section{Landmarks of identity}

The Arulmigu Tirumurugan temple of Montreal, located in the suburb of Dollard-desOrmeaux $^{8}$ and whose construction was completed in 2006, provides a good example of the importance of Tamil overseas temples for the unity, distinction and anchoring of diaspora communities in the public space in their host country.

This Hindu temple is far from being the only one in Canada which counts dozens in the area stretching from Quebec to British Columbia, yet it is the first to be founded by an exclusively Tamil community. After being sheltered for a few years within Montreal's Hindu Temple Society of Canada, whose temple is mainly frequented by Hindi-speaking Hindus from North India whose rituals and customs differ significantly from theirs (Bradley et al. 2006), in 1985 Sri Lankan Tamils from Montreal decided to found the Śaiva Mission of Quebec. The aim of this non-profit making public charity was 'the building of an authentic temple for their favorite god Lord Murugan, according to the Śaiva Āgama (texts revealed by the god Siva himself), and a centre to serve the social and cultural needs of the community'. ${ }^{9}$

Through its administration, its architecture and its tutelary deity, this large temple embodies the need of the Tamils of Montreal to pray to their gods in places of worship that are distinct and faithful to their own 'traditions'. Firstly, the communal administration of the temple allows them to gather together round the Tamil identity, while facilitating the establishment of Tamil socio-cultural activities such as linguistic and artistic teachings. ${ }^{10}$ Secondly, Murugan (or Murukan), ${ }^{11}$ the tutelary god of the temple, is so well known as the Tamils' regional deity that he is considered to be 'the 
Tamil God' (tamil katavul) par excellence. Thirdly, the building is the first in Canada to reflect the religious and architectural model of the Tamil Śaiva Agama as illustrated by the large sculpted tower (rāja $\bar{a}-g \bar{o} p u r a m$ ) indicating the entrance to the temple (Figure 1).

For all these reasons, this temple is a major haut lieu for the Tamils of Montreal. What is more, most of Montreal's Tamil Hindus attend this temple which is frequented quasiexclusively by Tamil people (Bradley, et al. 2006). (More details about the history and the modalities of the construction of this temple will be given later).

This Tamil particularism is neither recent nor specific to the Canadian context but concerns many territories of the Tamil migratory space. It already existed during the colonial period in 'plantation' countries, where about 1.5 million Indians left for contract work in the nineteenth century (Deerpalsingh \& Carter 1996). The example of Mauritius, which took in almost a third of these workers, is particularly telling in this respect, for it helps understand regional and religious Tamil particularism over the centuries.

We know, for example, that in the plantation camps on the island, after sharing the same shrines as North Indian Hindus, Tamils Hindus gradually individualized and separated their places of worship once they had been granted access to landed property (ChazanGillig \& Ramotha 2009). Moreover, their sanctuaries were primarily dedicated to South Indian deities, such as the goddesses Draupadī-Amman and Māriyamman, or the god Murugan (Sooriamoorthy 1989). Today still, the tutelary deities of Mauritian Tamil temples continue to differentiate Tamils from other Hindu communities: in 2008, of the 113 kōvil registered with the Mauritius Tamil Temples Federation, 68 had a goddess as their main deity, 39 were dedicated to Murugan, only 4 to Visnu, 2 to Ganēśa and, surprisingly, none to Śiva. In fact, in Mauritius, Śiva is a tutelary god of Tamil temples only under the name of 'Śiva Subrahmanien' (or 'Śiva Soopramanien', names that have been 'Creolised' from 'Śiva Subrahmanya') which is actually the name of his son Murugan. And when we realize just how much Murugan, or Subrahmanya, is associated with the Tamil identity, the fact that his name has supplanted Śiva's in Mauritian Tamil temples brings us back to the identity particularism of the Tamils, which is manifested by an overvaluing of their regional deities in comparison with the major pan-Hindu gods such as Śiva, Viṣnu and Gaṇēsa.

The largest Tamil religious festivals on the island, Tai Pūcam Kāvați and Cittirai Kāvați, are also dedicated to Murugan. They also contribute to differentiating Mauritians of Tamil origin from other Hindu communities, especially as this festive and religious differentiation is expressed visually in the public space by large processions (Figure 3), like practically everywhere else in the diaspora (Baumann 2006, Clothey 2006, Jacobsen 2008, 2009, Punzo-Waghorne 2004).

Similarly, since the mid-1990s, about half of Tamil shrines on the island have been redesigned as massive, colourful temples which pointedly highlight the presence of the Tamil community in the Mauritian landscape (Figure 4). Indeed, a process of orthodoxization-or 'Sanskritization'-of Tamil Hinduism has been taking place in Mauritius since the mid-1990s and notably consists in transforming ancient shrines into large temples according to the architectural precepts of the Ägama and in adorning them with gopuram, which was previously very rare on the island. The result is that, as in Montreal and often in the diaspora, these 'agamic' Tamil temples visually demarcate themselves from other Hindu temples on the island. 
Figure 3. Tamil religious procession for Murugan in Port-Louis, Mauritius (2008)

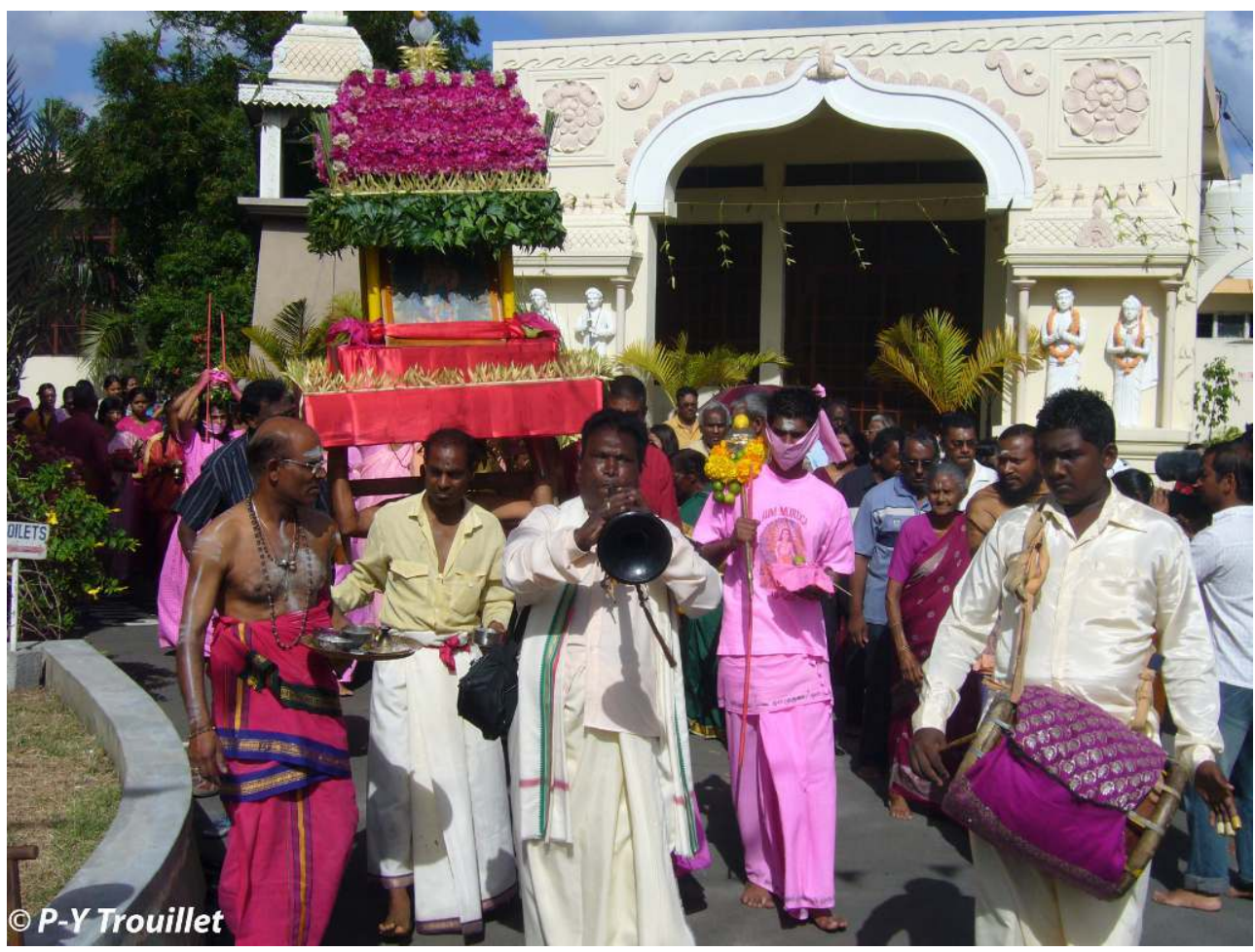

Figure 4. A restored Tamil temple on a sugarcane estate in Mauritius (2008)

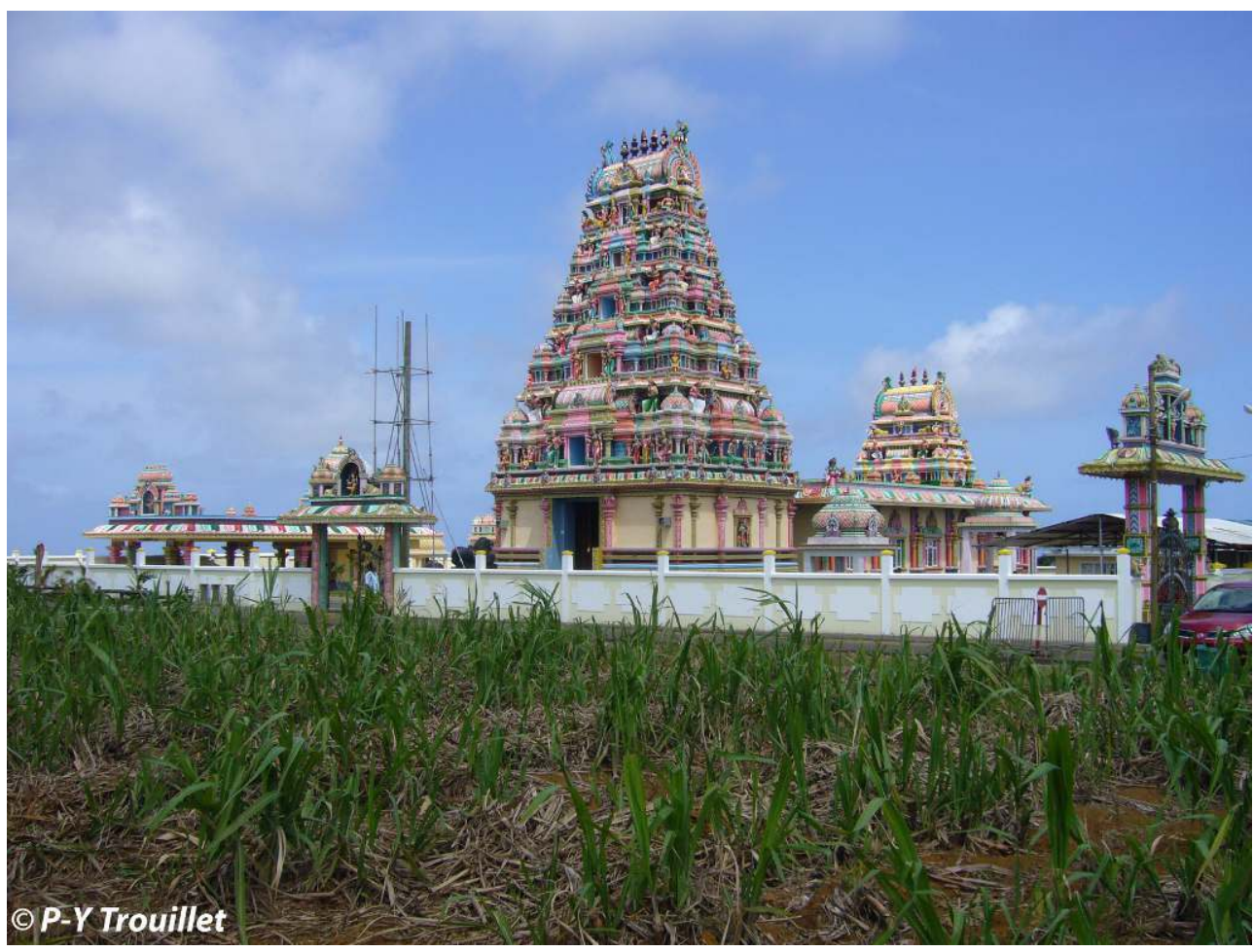

26 This correspondence between the temples and the particularization of the Tamil identity in Mauritius also emerges from the strong relationship between the geographical distribution of the kovil and the Tamil population (Figure 5). Over the centuries, the 
Tamils have marked Mauritian territory with their temples and produced a religious geography that today reflects the history of the Tamil population's settlement on the island. It shows how these places are first-order identity and territorial markers, as the Murugan temple of Montreal also suggests despite its lesser historical importance. Thus, kovil are logically privileged indicators of the Tamils' presence in the world's geographical space, and, as we will now see, of their identity affirmation in diaspora situations. Indeed, what are the reasons for such particularism? Why do Tamils use their temples to distinguish themselves from other Hindus in diasporic territories?

Figure 5. Locations of Tamil temples and Tamil Hindu population in Mauritius

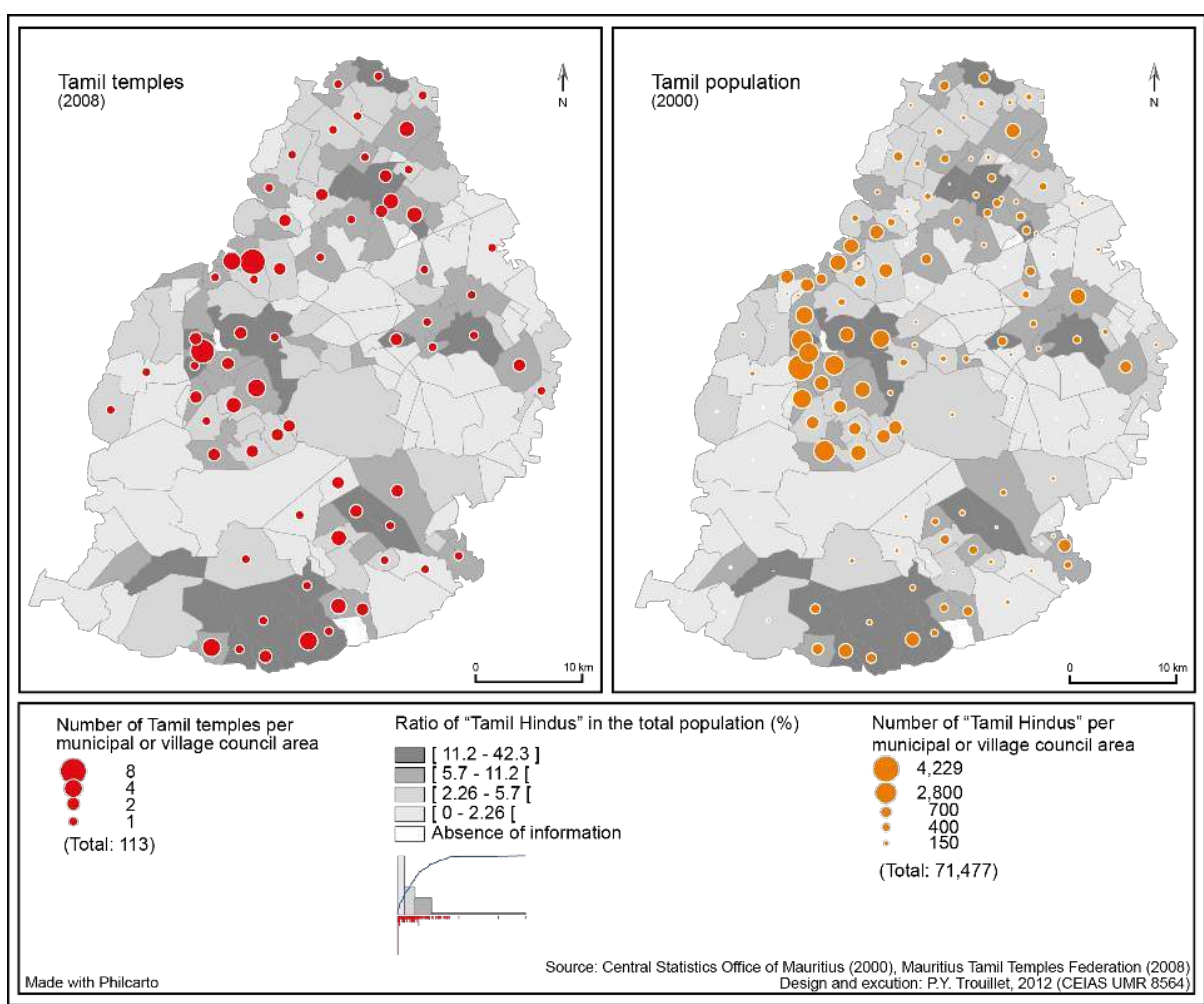

\section{The multi-polar roots of overseas ethnicity}

Political histories of home territories and host countries provide essential elements to understand this religious particularism. Indeed, the Tamil ethnicity expressed in the temples of the diaspora reflects the entanglement of political and identity issues at work in host countries and in countries of origin. It is a social construction of differences and 'ethnic boundaries' (Barth 1969) which started in India and Sri Lanka, and then became involved in issues relating to diasporic contexts. From this perspective, a study of the Tamil migratory space is essential to fully understand the identity claims of the Tamils through their diasporic temples.

Contemporary Tamil ethnicity is based on the ethno-linguistic concept of the 'Dravidian', which has profoundly marked the political scene of (Indian) Tamil country since the end of the $19^{\text {th }}$ century (Hardgrave 1965, Irschick 1969 \& 1986, Jaffrelot 2005, Pandian 1987, Ramaswamy 1997). This concept-category was introduced by Francis W. Ellis and Robert A. Caldwell who demonstrated the existence of a distinctive linguistic family in South 
India (Ram 1979). As the linguist William Jones had previously proved the existence of a family of Indo-European languages including Sanskrit, it led to the idea of a social, historical and 'racial' opposition between the two main linguistic groups of India, since at that time racial and linguistic categories were largely subsumed: on the one hand, the 'Dravidians' of the South, presented as the indigenous people of India and on the other hand, the 'Aryans' of the North, with a Sanskrit culture, and regarded as invaders and as those who introduced the caste hierarchy over which the Brahmins preside.

This theory was adopted at the turn of the $20^{\text {th }}$ century by the Dravidian Movement (Hardgrave 1965), an ideological and political movement which essentially developed in Tamil country. The aim was notably to challenge the dominance of Brahmins in the administration of the Madras Presidency by claiming the original primacy of the Dravidians over the Aryans (Irschick 1969, Jaffrelot 2005). The Dravidian Movement had considerable resonance in the regional political scene in Tamil country, which had been dominated since 1967 by regional parties resulting from this movement (Wyatt 2009). Its non (even anti)- Brahman ideology had a strong, long-lasting impact on political, social and religious life in Tamil Nadu, even if it has now been chastened (with the presence of a Brahmin as Chief Minister three times since 1991). Furthermore, Tamils repelled several times-sometimes even violently-the attempts of New-Delhi to impose the teaching of Hindi in Tamil Nadu schools (Ramaswamy 1997).

31 The role played by the Tamils of Jaffna since the end of the nineteenth century in the Tamil cultural and identity revival should also be emphasized. The city was indeed a major place for Tamil literary culture at that time (Francis 2012). Many Sri Lankan Tamils have worked for the revival and modernization of the Śaivist religion, and some of them were very active in the Dravidian nationalism movement (Francis 2012). Furthermore, despite specifically national issues, the nature of the conflict between predominantly Buddhist Sinhalese and Tamil Hindus of Sri Lanka brings to mind the opposition between Dravidians and Aryans, as the Sinhalese language and Theravāda Buddhism are also of Indo-Aryan origin.

The expression of Tamil ethnicity in the temples of the diaspora must therefore be understood in light of the identity and socio-political issues imported from the territories of origin, but also in considering the context in the host countries.

The importation of Tamil-Dravidian ethnicity is particularly visible in Mauritius. Yet it cannot be understood without underlining the fact that Tamils represent a minority on the island, both demographically and politically, in comparison to the Hindus from the North of India (from present-day Bihar and Uttar Pradesh) who speak Bhojpuri. ${ }^{12}$ Indeed, the Bhojpuris represent the first Indo-Mauritius community, following their massive immigration in the $19^{\text {th }}$ century, and they have invariably dominated national politics since Independence in 1968. In addition, they promote a Hinduism of Sanskrit and North Indian tradition which, as a result, relegates the Tamils, symbolically and politically, to the rank of second-class Hindus (Carsignol 2011).

In this context, the Dravidian identity, after being (re)conceptualized in South India, as well as the temples and religious festivals similarly imported from the country of origin, represent a valuable means of symbolic and identity resistance for Tamils in Mauritius. This is all the more important since the Tamil language has not withstood the centuries of presence on the island and can no longer play its role to cement this identity, as in South India. Their identity resistance therefore developed especially around religion to oppose Bhojpuris, to the extent that a distinct 'Tamil' religion separate from Hinduism 
was set up in the middle of the $20^{\text {th }}$ century (Murugayan 2003). Since then, a Mauritian of Tamil origin must not be said to be 'Hindu', even if he worships the Hindu gods in temples. He will call himself 'Tamil', not 'Hindu', because this term is now reserved for Hindus from the North of India who speak Bhojpuri.

This distancing of Tamils from other Hindus is most prevalent in Mauritius and is not apparent in countries where they represent the majority of Hindus (as in Sri Lanka, Malaysia, Reunion, or metropolitan France, for example), which indicates the importance of local contexts in the expression of Tamil ethnicity in the diaspora. Nevertheless, in recent years this distancing has emerged in Canada as well, where Tamils of Sri Lankan origin are also a minority among Hindus, just as in Mauritius, and they distinguish their places of worship by speaking of their temples as specifically 'Tamil', not 'Hindu'. Similarly, Hindu identity is also left to the North and West Indian Hindus-who make up the majority of South Asian immigrants in Canada ${ }^{13}$-to the benefit of a specifically 'Tamil' identity.

Thus, temples of the Tamil diaspora may be indicators of how these migrants affirm their identity in the host country's public space, which cannot be understood without taking into account the political and communal issues of the two main poles of the migratory space, which are the host countries and the homelands. These temples and the religious festivals that take place in and around these landmarks, especially processions, are symbols and spatial markers of a particularism imported from territories of origin, which develop more or less according to the host country's communal issues and the local status of the Tamil community.

\section{Arenas for multi-scale political issues}

37 The temples of the Tamil diaspora are not only ritual and symbolic places displaying an ethno-religious identity in the public space. They are also community places that rally round political causes involving national or transnational stakes, where various territories of the migratory space once again have their importance. Although large political demonstrations are relatively rare near the diaspora's temples, Tamils occasionally take action there and make speeches calling upon issues and references taken from various diasporic spaces and concerning different scales.

At intercommunal level in the host country, the Tamil temple is not really a place of political demonstration, even though, as in India, politicians do come from time to time, and political posters can sometimes be found around places of worship. Its political importance is based mainly on its ability to gather the Tamil community together in one place where many awareness campaigns about national political issues or regarding the situation of Sri Lankan Tamils can be organised.

In Mauritius, Tamil temples play a major role in raising community awareness, for it is in fact during temple festivities that 'Tamil Force' activists find the best opportunity to promote what they call the 'Tamil cause' among their co-religionists. The Tamil Force is a protest movement which was formed in 2008 after the dissolution of the Tamil Council, the Tamil political party, which had replaced the Tamil United Party in 1976. According to its active members, the Tamil Force is intended to 'remember the greatness of Tamil culture, to mobilize against the injustice faced by the Tamils and to denounce their oppression by the 'Hindus' [sic., i.e. the Bhojpuris] ${ }^{14}$. For Tamil Force activists, the kōvil are essential places for the community to meet and to increase its awareness. This was 
notably the case in 2008 on the last evening of the Govinden (Kōvintan) Festival at the Mont-Roches temple, in front of which militants had displayed their movement's banner representing a roaring Tiger, referring to the Liberation Tigers of the Tamil Eelam (LTTE) of Sri Lanka.

This example illustrates the importance of the migratory space in the politicization of Tamil diaspora temples. It shows how, in the communitarian context of Mauritius, political problems in the territories of origin are imported and mixed with domestic issues in the host country. Indeed, to sensitize the Mauritian Tamils to the importance of their unity and to defend their interests against the Bhojpuri majority, the Tamil Force associates Dravidian, ethnicist and anti-North Indian ideology imported from South India with the problems faced by the Tamils of Sri Lanka. In their speeches as well as their leaflets, the Bhojpuris are presented by the Tamil Force as the eternal oppressors of Tamils for they are of Aryan origin, and the Sri Lankan context is described like hell, threatening Mauritian Tamils if ever they lose their unity. The roaring tiger printed on banners, leaflets and activists' $t$-shirts is also a very explicit illustration of the references used by the movement. And temples are indeed the main venues for spreading this ideology, which mixes national politics, Dravidian ethnicity and 'long-distance nationalism' (Anderson 1992, Fuglerud 1999). The local, national and transnational are thus interwoven by the politicization of the Tamil temples in Mauritius.

The case of the Tamil Force in Mauritius also illustrates the importance of the Sri Lankan conflict in the politicization of the diaspora and in the awareness of Tamil transnational identity, even in communities originating from South India. The conflict, exile and abuse suffered by Tamils during the civil war have actually fuelled a sense of belonging to the diasporic community, a transnational solidarity and long-distance nationalism. According to Jacobsen (2009: 183), 'the misfortune of the Tamils in the modern nation state of Sri Lanka is an important context for understanding the religious rituals in the Sri Lankan Tamil diaspora'... but also in the South Indian one.

During the civil war, this transnational dimension of Tamils joining forces to defend the Sri Lankan cause was manifested in some temples of the diaspora, which have been used to raise awareness about the Sri Lankan Tamils humanitarian and political predicament. Outside the temples of the Sri Lankan diaspora, as in Montreal or Paris, NGOs such as the Tamils Rehabilitation Organization (TRO) distributed leaflets and raised funds on the occasion of large religious gatherings. These awareness-raising activities have ceased since the end of the war in 2009, especially as the Sri Lankan Tamil diaspora is divided on the question of which path to follow today. Let us not forget that since 2006, TRO actions have been very limited, since the United States Department of the Treasury and the European Union have recognized it as a terrorist organization funding the activities of LTTE.

43 Finally, let us mention the pro-LTTE demonstration that was organised on May 242009 in the large Tamil temple in the Batu Caves, near Kuala Lumpur, where the tallest statue of Murugan in the world (140 feet) was erected. While most of the demonstrations led by the diaspora during the last hours of the civil war took place mostly in front of embassies or in public places (Miller et al. 2010), this one was clearly intended to lend a religious dimension to the demand for an independent Tamil State in Sri Lanka (Madavan 2010).

In countries of the Tamil diaspora, temples are therefore key places concerning the visibility of Tamil political causes, at local and international levels, and in which the migratory space plays a major role, particularly in terms of identification with the Tamil 
transnational community. The Mauritian case shows how the political situations in South India and Sri Lanka provide meaningful arguments for domestic political competitions, with issues being recalled during temple celebrations. Conversely, the diaspora temples of Sri Lankan Tamils, such as those in Montreal, Paris or the Batu Caves, lend international visibility to their national conflict. In fact, as places for community gatherings and for expressing Tamil political identity, overseas temples are seemingly places that are unequalled in the Tamil diasporic space, which confirms their status of hauts lieux.

\section{Hauts lieux of transnational flows and spatial rhetoric}

For those interested in the genesis of overseas Tamil temples, in the exchanges they engender, or even in their inner space, some of these temples appear to be hauts lieux of transnational relations between diasporic communities, as well as religious sites whose sanctity is partly based on identification with the holy places of the homeland.

\section{Transnational networks}

Arjun Appadurai (1996), Christophe Jaffrelot and Ingrid Therwath (2007) have clearly demonstrated the existence of transnational relations and mobilizations within the 'Hindu diaspora'. Concerning overseas Tamil temples, those built over the past thirty years have benefited from the intensification and acceleration of transnational exchanges. Nevertheless, not all the temples of the Tamil diaspora receive transnational support, starting with those founded in the plantations during the colonial period, which have been, and still are, based on a much more local mobilization.

On the whole, overseas Tamil temples should not be considered as isolated places in spite of their geographical dispersion, since they sometimes have links with social networks of an international dimension. This is notably the case of the large Arulmigu Tirumurugan temple in Montreal, whose genesis is very evocative of the transnational networks currently available to the Tamil diaspora (Figure 6). 
Figure 6. Transnational mobilization for the construction of the Murugan temple in Montreal (per country, Canada excluded)

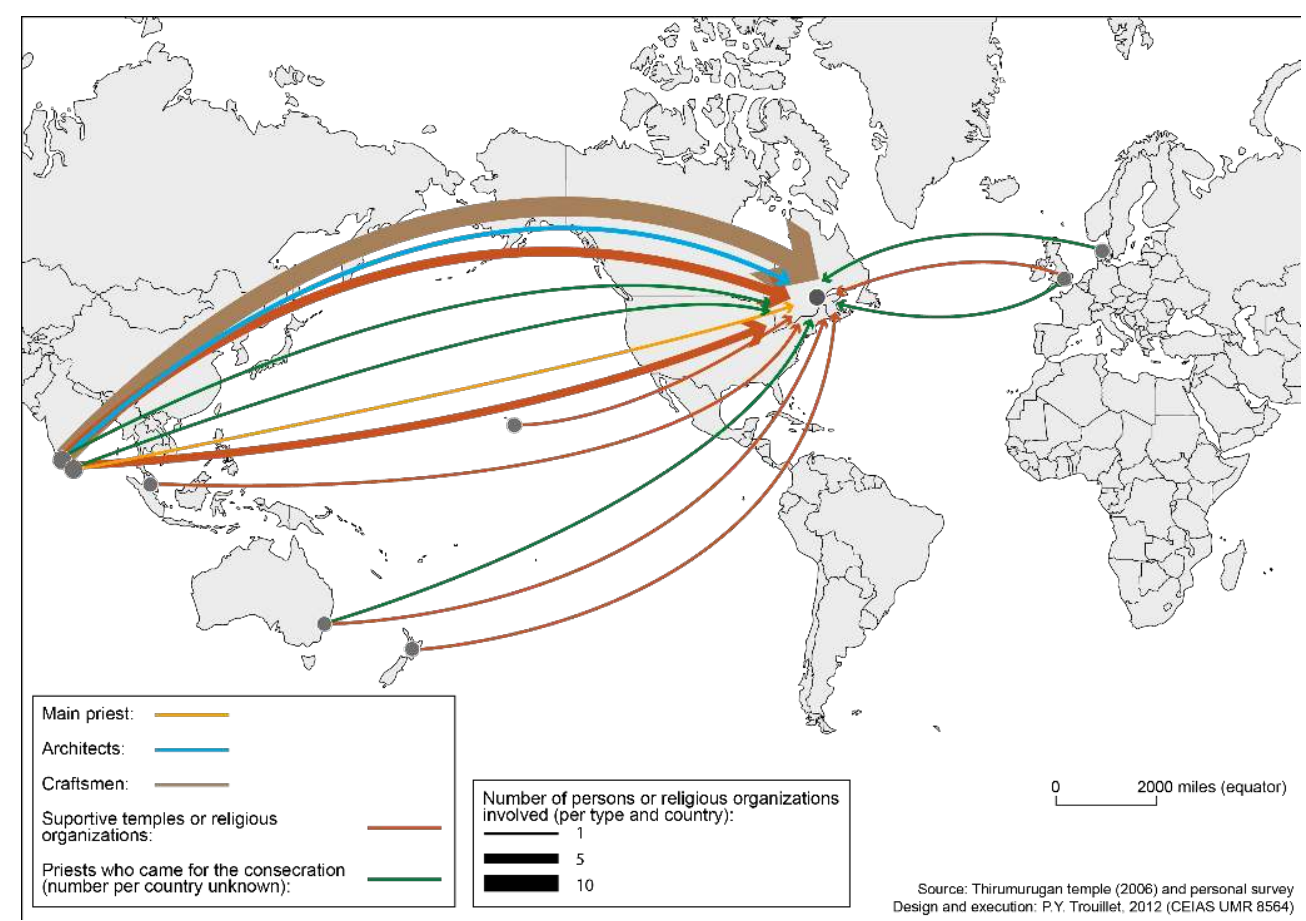

48 As in the homeland, for this 'agamic' temple to function properly, the originators first had to call upon a referent priest (stānikar) to officiate at the temple. This role was assumed by a native Sri Lankan Brahmin who belongs to the Ādiśaiva sub-caste (the 'original Śaivas' also known as Śivācārya, i.e. 'priests of Śiva'), agamic priesthood specialists. To build the temple, the founders turned to specialists with the required skills in building science (vāstuśāstra) and a thorough knowledge of the Āgama. Two architects ( stapati) specialising in the construction of agamic temples were chosen. They came from Tamil Nadu. The first one was in charge of planning the temple structure, of getting the work started, and then of the 'sod turning' (ground-breaking) ceremonies. The second one supervised the construction of the building, which was done by twelve craftsmen ( cirpi) who also came specially from Tamil Nadu. Thus we can already see a first diasporic aspect of the construction of this temple, but the transnational dimension of this religious haut lieu in Montreal does not stop there.

Indeed, to celebrate the ritual consecration (makākumpapișēkam) of the temple in 2006, many Tamil Indian and Sri Lankan priests also came from other Canadian cities, from the United States and even from Europe and Asia where they were employed at the time, to assist the referent priest. Moreover, the construction of the temple received the support of about twenty temples and Tamil religious organizations from all over the world: five based in Tamil Nadu, four in Sri Lanka (Jaffna district), five in Canada, one in Malaysia, another in London, one in Australia, one in Hawaii and one in New Zealand. The Murugan temple in Montreal is therefore a good example of the transnational networks that are called upon for the construction and ritual life of diasporic temples. Furthermore, its construction mobilized a fairly representative-though not exhaustive-network of the Tamil migratory space, in which the countries of origin, India and Sri Lanka, appear to be logically the main poles. 
It is also worth noting that the social networks that contributed to the construction of this temple were not only transnational. There were indeed three levels and three types of diasporic spaces that intersected to create this haut lieu. The first was at local level, the city of Montreal, where in 1985 Hindu Tamils founded the Śaiva Mission of Quebec, as mentioned above. It was only when this local mobilization had been achieved that other actors could be mobilized on other scales, i.e. in Canada, within the diaspora and in the homelands. Thus, although all Canadian or diasporic Tamil temples did not benefit from such a degree of involvement when they were founded, this example shows how building an overseas temple today can bring together a wide range of actors scattered over the Tamil migratory space by combining local, national and transnational involvements.

\section{Priests on the move}

Temples are also poles and anchorage points for numerous movements within the Tamil migratory space. They encourage international movement for religious-tourist purposes generally though not exclusively to India. There are indeed other international poles of Hindu religious tourism, such as the great sanctuary in the Batu Caves in Malaysia or other ones in Mauritius, which are visited by pilgrims from India and the diaspora.

With regards the construction and everyday running of overseas temples, these movements primarily involve ritual objects-starting with statues of deities (mürti) imported from India to preside over holy places-, capital to finance work or religious events, and, as we have seen, specialists such as architects, craftmen and especially officiating priests who are the major actors at any Tamil temple.

The example of the great temple of Montreal shows that priests from India and Sri Lanka travel the world to officiate at some of the overseas Tamil temples. These priests travel abroad on a work contract which may last from several years to only a few days, in the case of religious festivals. Most of these priests belong to the Ādiśaiva (or Śivācārya) caste. Some return to India at the end of their contract, like T. Gurukal ${ }^{15}$, an Indian priest who usually works in Chennai and who has been twice to Canada, each time for two years (between 1999 and 2005), as officiating priest at a Tamil temple. The referent priest from the Canadian temple came to Chennai to ask for his assistance at the temple and fully funded his stays. On both occasions, T. Gurukal left his family behind, like the majority of Tamil priests officiating in the countries of the diaspora, as he never envisaged settling there. ${ }^{16}$

Other priests travel between their country of origin and one or several countries moving from one contract to another. This is the case of the majority of Indian priests working on the island of La Réunion who travel essentially between India and the Creole island. Others, such as V. Ayyapan, have more diverse routes. The latter usually officiates in a village in Tamil Nadu, but he also worked in Kuala Lumpur in 1997, the following year in Singapore and then for five years in Mauritius (2006-2011), where his family circle is well represented. He is very motivated by his life as a mobile priest, and would like to go to London or to Italy where he has some contacts, to return to Kuala Lumpur or even to work in North India for a while, although in his case too, his family remains behind in Tamil Nadu each time he travels. ${ }^{17}$

Other officiating priests, usually of Sri Lankan origin, end up staying in the host country. This is notably the case of the referent priest of the great temple of Montreal, as well as many other priests working in Mauritius or even France. The priest at a Parisian temple, 
for example, settled in the capital after becoming referent priest and marrying a French Tamil, which enabled him to apply for dual nationality. Before that, he had worked in Singapore, Malaysia and India, which confirms the diversity in the movement of these priests in the Tamil migratory space. Now a father, he no longer wishes to return to Sri Lanka where the Tamil situation remains complicated. ${ }^{18}$

A distinction must be made between the spatial mobility of Indian and Sri Lankan Tamil priests. The former's mobility is related to economic and professional strategies with an idea of returning, while Sri Lankan priests must cope with the difficulties inherent in their homeland. Many of them also benefit from political refugee status, especially in Western countries, which allows them to stay. Nevertheless, this mobility is always regarded in terms of resources, or even, for Indian priests, in terms of skills and profits generated by their coming and going, to the extent that a 'circulatory know-how' sometimes develops (Tarrius 1996), which up to now was associated with trading castes. The mobility of these religious actors is neither unidirectional nor limited to international recruitment, since officiating priests also move from host countries to the countries of origin for training purposes. These moves are much more recent and marginal. They notably concern Mauritian priests who leave to train in Tamil Nadu, at the temple-monastery in Perur (Pērūr Âtinnam) near Coimbatore. Some of them go there for their ordination ceremony after having trained at new schools for priests based in Mauritius, which are affiliated with Perur monastery. This link between Mauritian Tamils and the temple-monasteries in Tamil Nadu must be taken into consideration as a new aspect of the relationship between the temples and the Tamil migratory space.

Some actors involved in the life of diasporic temples may intervene in several places in the migratory space and in various projects, sometimes even concomitantly. Indeed, Santhalinga Ramasami Adigal, the spiritual authority of the Perur temple-monastery, which is very active in the training of Mauritian priests, also supported the construction of the great temple of Murugan in Montreal.

Transnational movements of priests contribute to the ritual and cognitive reconstruction of the spatial continuity between the host country and the land of origin where holy places of reference are located. However, overseas Tamilians have recourse to another effective tool for this purpose: the temple replica.

\section{Replicas worldwide}

The final major aspect of the relationship between overseas temples and the Tamil migratory space concerns the replicas of homeland shrines in host countries. Many studies on diasporic Hinduism have insisted on the adaptations of religious practices, but logics of replication and imitation of existing temples also deserve attention because they reinforce the cognitive relationship between the Tamils of the diaspora and the holy land of origin. Indeed, increasingly complex temple replicas appear in different corners of the migratory space, and some go as far as representing this transnational space in the ritual space of their own sanctuary.

61 A first type of replica simply consists in a diasporic community's identification of an overseas temple with an original temple. This is particularly the case of the temple Śiva Soopramanien Kōvil (SSK) in Mauritius, founded in 1897 by a Tamil coolie and which has become one of the two main Tamil temples on the island. Today it is nicknamed the 
'Palani of Mauritius' in reference to the great shrine of Tamil Nadu dedicated to Murugan. Palani is indeed the world's most important pilgrimage centre dedicated to this deity, and the most visited temple in Tamil country (Trouillet 2010). The SSK owes its nickname to the large-scale pilgrimage it attracts each year and to its location on a mountainside, recalling the original Palani set atop an inselberg. As in Tamil Nadu, the pilgrimage to the Mauritian Palani is characterized by huge processions of devotees carrying kāvati-ritual loads adorned with peacock feathers characterizing the worship of Murugan-and, since 1998, its referent priest has also been a Śivācārya Brahmin. Nevertheless, these two temples do not share the same founding myth and have no officially established rituals or architectural links.

Mauritius has three other replicas of Palani, one in Grand-Baie and the others in Mount Ory and Tranquebar. Although these temples are less well-known than SSK, the ritual and mythical form of the deity in the Tranquebar kōvil-Tanțāyutapāni-is the same as the one in the original Palani temple. We can see that this type of replica is not reserved for Palani, since Tranquebar is primarily a locality in Tamil Nadu, but also because there are three 'Madurai'19 temples in Mauritius (one in Helvetia and two in Port-Louis). This phenomenon is not the exclusive domain of the Tamils, because the Bhojpuris built a replica of Śri Kāśĩ Viswanath Mandir in Vārānasīi near the large Gangā Talao Lake, which takes its name from the water of the Ganges that was poured into it in 1972 and which is now considered to be a resurgence of the holy lake (Carsignol 2011). There is also a village called 'Benares' in the southern part of the island.

Another type of replica concerns the reproduction of several religious places from the homeland in a single overseas sanctuary. This is the case of the great temple of Murugan in Montreal which has already been mentioned, featuring representations of the six most important holy places dedicated to this deity in Tamil Nadu (Palani, Tiruttani, Tiruccentūr, Svāmimalai, Tirupparañkuñram and Palamutircōlai) within its sanctuary. Its large pavilion (mahā-mandapam) rests on six ritual pillars, each adorned with a sculpture representing Murugan in one of his 'Six Abodes' (Āru Pațai Vịtu). Joanne Punzo-Waghorne (2004: 204-5) made a similar observation at the Lakșmī temple in London's East Ham district, where wooden miniatures represent these six temples and receive daily rituals. Another example is found in the SSK temple, in Mauritius, the inner mandapam of which is also decorated with six paintings depicting Murugan's Tamil abodes. It is worth noting that in Montreal and East Ham, it is the Tamils of Sri Lanka who set up these Tamil Nadu temple replicas in their sanctuaries, which seems to indicate the primacy of Tamil country as the holy land of reference for the Tamil diaspora, even for those who come from Sri Lanka.

This profusion of replicas is explained by the fact that this practice also exists in India to make distant holy places accessible ${ }^{20}$ (Eck 1998, Feldhaus 2003), but it is a much more pronounced problem in the diaspora. All the temples of the Tamil diaspora strengthen the collective memory and the ritual ties with the religious places of the homeland. Yet with the replicas of original temples, the goal is to make these temples symbolically present in the host country and thus cancel out the distance imposed by migration. In the case of the replicas of Murugan's six abodes, it is even the sanctuary of the regional Tamil deity, indicated by these six hauts lieux, which is reproduced. And in so far as Tamil Nadu is considered to be the sacred homeland of Murugan (all these six original temples are located there and four of them mark its political boundaries), the holy land of origin is also made present indirectly in these temples. 
A third logic of replication, contrary to the previous one, seems to be emerging nowadays. Indeed, the Âru Pațai Vịtu Complex, a new Chennai sanctuary also dedicated to Murugan and inaugurated in 2002, shows that some of the Tamil diaspora's temples can also be replicated in India. Moreover, this temple is rather original, for it must be seen as a 'transnational' sanctuary: firstly, because its managers (trustees) define it as a 'temple of Non-Resident Indians' ${ }^{21}$ in so far as each of them has a US green card; secondly, because the founder of the temple is also the founder of the first Tamil temple in New York, Mahā Vallabha Ganapati (Gan̄éśa) temple; and finally, because this new sanctuary gathers together the replicas of the six regional Murugan temples around the replica of this New York temple (Figure 7).

Figure 7. Sketch of the 'glocal' temple of Murugan in Chennai

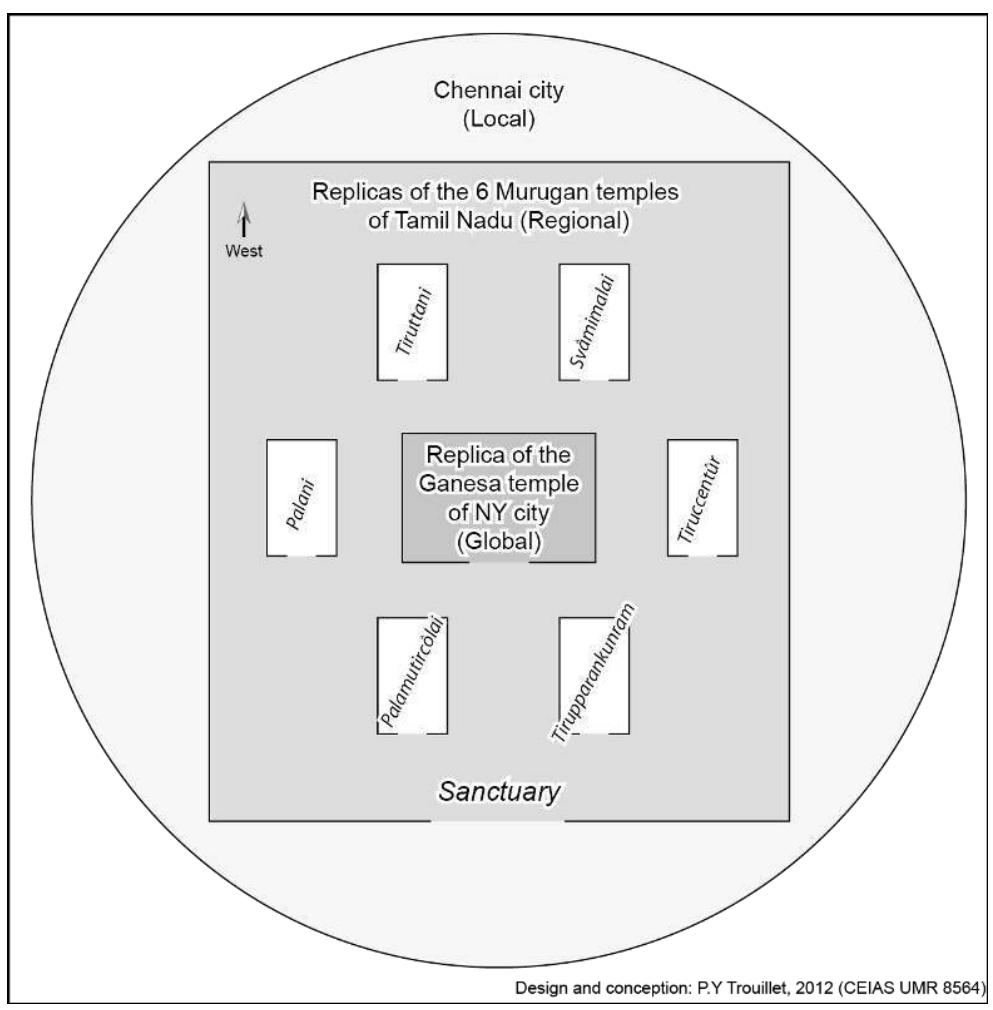

Thus, by including the 'regional' (the six Murugan temples) and the 'transnational' (the temple of New York and the NRIs) in the 'local' (a temple in Chennai), this sanctuary illustrates by its inner space the wealth of possible relationships between the temples of the Tamil diaspora and its migratory space. It attests to the Hindu ability to play with places and scales in sanctuaries, and shows how the temples of the Tamil diaspora enable identification with both a territory of origin and a transnational space by ritualistic, symbolic and geographic processes, all of which can be very innovative.

\section{Conclusion}

The overseas Tamil temple is not just a place where service is paid to the gods of the homeland, but also a haut lieu for religious, socio-cultural and sometimes political rallies. As such, it is also a local symbol of the Tamil identity which distinguishes itself from other communities and which takes root in the territory of the host countries. The need 
for such places for Tamil societies scattered over the world has given rise to transnational mobilizations and circulations of goods, capital and people, which constitute a primary aspect of the relationship between the temples of the diaspora and the Tamil migratory space. Another type of relationship concerns temple replicas, which attest to the strength of the link between the Tamil diaspora and the temples of the homeland, to the extent that these holy places are replicated at different locations in the migratory space. The realms of politics and identity are also at the heart of the relationship between the overseas Tamil temple and the migratory space, because the situation revolving around these temples cannot be understood without taking into account the political and communal issues at stake in the country of origin, in the host country and in the transnational Tamil community. Consequently, the issues in the three constituent parts of the Tamil migratory space sometimes locally overlap in the diasporic community's temples.

Overseas Tamil temples confirm the hauts lieux status they have in South Asia. Due to their religious and symbolic scope, they help to reduce the distance between the diasporic devotees and the gods of their holy homeland, and even to cancel it out in the case of replicas. In the territorialization of communities scattered over their host countries, they act as identity markers and anchorage points for deities and communities in the public space. As such, the overseas kōvil is a sign and a signature of the Tamil presence in the landscape. But it also takes the form of a stage, a stage for affirming an identity and a stage for rallying a community. Finally, temples appear to be crucial links in multiple networks, centres with no equivalent in the Tamil migratory space.

The work of Bernard Debarbieux $(1993,1995)$ on the symbolism of spaces shows that some hauts lieux may, through rhetorical games such as the synecdoche, mean the territory encompassing them, where the part represents the whole, as, for example, Mont Blanc for France or the Taj Mahal for India. From this point of view, it is not only the affiliation to a home territory that is evoked by the spatial rhetoric of the temples of the Tamil diaspora, but also the Tamil migratory space itself. Indeed, the 'sense of place' of these overseas temples refers, depending on various processes, to the space of transnational sociability which includes and produces them, and for which they are entirely important. Overseas Tamil temples thus exemplify the concept of haut lieu and also enhance it, in so far as they ensure the introduction of the network, and mobility as well as 'de-territorializationreterritorialization' issues, in the spatial rhetoric of such places.

\section{BIBLIOGRAPHY}

Anderson, Benedict (1992) 'The New World Disorder', New Left Review, (193), May/June, pp. 4-11.

Appadurai, Arjun (1996) Modernity at large: Cultural Dimensions of Globalization, Minneapolis: University of Minnesota Press.

Appadurai, Arjun (2008) Worship and Conflict under Colonial Rule: A South Indian Case, Cambridge: Cambridge University Press, [1981]. 
Barth, Fredrick (ed.) (1969) Ethnic Groups and Boundaries: The Social Organization of Culture Difference, Boston: Little, Brown and Company.

Basch, Linda; Glick-Schiller, Nina; Szanton Blanc, Christina (1994) Nations Unbound, Transnational Projects: Post-colonial Predicaments and De-territorialized Nation-States, Langhorne: Gordon and Breach.

Baumann, Martin (2006) 'Performing Vows in Diasporic Contexts: Tamil Hindus, Temples, and Goddesses in Germany', in Selva J. Raj; William P. Harman (eds.) Dealing with Deities: The Ritual Vow in South Asia, Albany: State University of New York, pp. 129-44.

Benoist, Jean (1998) Hindouismes créoles: Mascareignes, Antilles, Paris: Editions du CTHS.

Bonnemaison, Joël (1981) ‘Voyage autour du territoire’, L'Espace géographique, 10(4), pp. 249-62.

Bordes-Benayoun, Chantal (2009) 'Cultes et rituels en mouvement' in Virginie Baby-Collin, Geneviève Cortes, Laurent Faret \& Hélène Guétat-Bernard (eds.), Migrants des Suds, Marseille: IRD, Presses universitaires de la Méditerranée.

Bradley, Mark; Theophile, Julien; Boisvert, Mathieu (2006) 'Le temple tamoul hindou Thiru Murugan de Dollard-des-Ormeaux', Cahiers de recherche de l'UQAM, 19, pp. 1-16.

Bradley, Mark; Trouillet, Pierre-Yves (2011) ‘Le temple et les défunts: Religion et reconstruction identitaire chez les Tamouls hindous d'origine sri lankaise à Montréal', Hommes et Migrations, 1291, May-June, pp. 116-27.

Carsignol, Anouck (2011) L'Inde et sa diaspora: influences et intérêts croisés à l'Ile Maurice et au Canada, Genève: Presses Universitaires de France, Graduate Institute.

Chazan-Gillig, Suzanne; Ramotha, Pavitranand (2009) L'hindouisme mauricien dans la mondialisation: cultes populaires indiens et religion savante, Marseille \& Moka: Karthala-MGI-IRD.

Claveyrolas, Mathieu (2010) 'L'ancrage de l'hindouisme dans le paysage mauricien: transfert et appropriation', Autrepart, 56(4), pp. 17-37.

Clothey, Fred W. (2006) Ritualizing on the Boundaries: Continuity and Innovation in the Tamil Diaspora, Columbia SC: University of South Carolina Press.

Cohen, Robin (1997) Global Diasporas: an Introduction, London \& Seattle: UCL Press \& University of Washington Press.

Dayalan, D. (1992) Early Temples of Tamilnadu: Their Role in Socio-Economic Life (c. A. D. 550-925), New Delhi: Harman Publishing House.

Debarbieux, Bernard (1993) 'Du haut lieu en général et du mont Blanc en particulier', L'Espace géographique, 22(1), pp. 5-13.

Debarbieux, Bernard (1995) 'Le lieu, le territoire et trois figures de rhétorique', L’Espace géographique, 24(2), pp. 97-112.

Debarbieux, Bernard (2003) 'Haut lieu', in Jacques Lévy; Michel Lussault (eds.), Dictionnaire de la géographie et de l'espace des sociétés, Paris: Belin, pp. 448-49.

Deerpalsingh, Saloni; Carter, Marina (eds.) (1996) Selected Documents on Indian Immigration: Mauritius, 1834-1926, vol. 2, Moka (Mauritius): MGI Institute Press.

Dequirez, Gaëlle; Madavan, Delon; Meyer, Eric (eds.) (2011) Les communautés tamoules et le conflit sri lankais, Paris: L'Harmattan.

Eck, Diana (1998) 'The Imagined Landscape: Patterns in the Construction of Hindu Sacred Geography', Contributions to Indian sociology, 32(2), pp. 165-89. 
Feldhaus, Anne (2003) Connected places: Region, Pilgrimage, and Geographical Imagination in India, New York: Palgrave Macmillan.

Foucault, Michel (1986) 'Of Other Spaces’, [transl. by Jay Miskowiec], Diacritics, 16(1), pp. 22-27, [1967].

Francis, Emmanuel (2012) ‘Un pont pour Lañkā : Sri Lanka et l'Inde du Sud dans l'histoire et l'historiographie', paper presented in the conference on Et l'histoire dans tout ça ? Retour sur la place de l'histoire dans les études indiennes, Centre for South Asian Studies, Paris, 03/05/2012.

Fuglerud, Øivind (1999) The Tamil diaspora and long distance nationalism, London: Ed. Pluto Press. Goreau-Ponceaud, Anthony (2011) 'Tamils in France', in S. I. Rajan \& Marie Percot (eds.), Dynamics of Indian Migration: Historical and Current Perspectives. New Delhi: Taylor \& Francis Group, pp. 64-90. Guilmoto, Christophe Z. (1987) 'Démographie et politique : les Tamouls entre Sri Lanka et l'Inde', Population, 2, March /April, pp. 283-303.

Guilmoto, Christophe Z. (1991) 'Le cycle migratoire tamoul, 1830-1950', Revue Européenne des Migrations Internationales, 5(3), pp. 65-77.

Hardgrave, Robert L. (1965) The Dravidian Movement, Bombay: Popular Prakashan.

Irschick, Eugene F. (1969) Politics and Social Conflict in South India: The Non-Brahman Movement and Tamil Separatism, 1916-1929, Berkeley: University of California Press.

Irschick, Eugene F. (1986) Tamil Revivalism in the 1930s, Madras: Cre-A.

Jacobsen, Knut A. (ed.) (2008) South Asian Religions on Display. Religious Processions in South Asia and in the Diaspora, London: Routledge.

Jacobsen, Knut A. (2009) 'Establishing Tamil Ritual Space: A Comparative Analysis of the Ritualisation of the Traditions of the Tamil Hindus and the Tamil Roman Catholics in Norway', Journal of Religion in Europe, 2, pp.180-98.

Jaffrelot, Christophe (2005) Inde: la démocratie par la caste. Histoire d'une mutation socio-politique 1885-2005, Paris: Fayard.

Jaffrelot, Christophe; Therwath, Ingrid (2007) 'Le Sangh Parivar et la diaspora hindoue en Occident : Royaume-Uni, États-Unis et Canada', Questions de recherche, 22, Paris: CERI, 70 p.

Madavan, Delon (2010) '2009 pro LTTE demonstration at Batu Caves (Malaysia)', Sri Lanka \& Diaspora: observatoire pluridisciplinaire, URL : http://slkdiaspo.hypotheses.org/499

Meyer, Eric (2001) Sri Lanka, entre particularismes et mondialisation, Paris: La Documentation Française.

Miller, Frederic P.; Vandome, Agnes F.; McBrewster, John (eds.) (2010) 2009 Tamil diaspora protests, Alphascript Publishing.

Murugayan, Appasamy (2003) 'La presse bilingue tamoule-française à Maurice et la construction d'une identité tamoule', in R. I. Kumari \& V. Y. Hookoomsing (eds.), L'Océan Indien dans les littératures francophones, Réduit: Karthala \& Presses de l'Université de Maurice, pp. 287-312.

Nora, Pierre (ed.) (1984-1992) Les lieux de mémoire, Paris: Gallimard, 7 vol.

Pandian, J. (1987) Caste, Nationalism and Ethnicity: An Interpretation of Tamil Cultural History and Social Order, Bombay: Popular Prakashan.

Punzo-Waghorne, Joanne, (2004) Diaspora of the Gods. Modern Hindu Temples in an Urban Middle-Class World, New York: Oxford University Press. 
Ram, N. (1979) ‘Dravidian Movement in its Pre-Independence Phases', Economic and Political Weekly , 14(7-8), pp. 377-402.

Ramaswamy, Sumathi (1997) Passions of the Tongue: Language Devotion in Tamil India, 1891-1970, Berkeley: Berkeley University Press.

Ranganathan, Maya (2011) Eelam online: The Tamil Diaspora and War in Sri Lanka, Cambridge: Cambridge Scholars Publishing.

Rukmani, T.S. (ed.) (2001) Hindu Diaspora. Global Perspectives, New Delhi: Munshiram Manoharlal Publishers.

Saiva Mission of Quebec (2006) Thirumurugan Temple Montreal: Souvenir of the Consecration Ceremony , Saiva Mission of Quebec: Montreal.

Saiva Mission of Quebec (not dated) Thiru Murugan Temple: Devotees Guide, Saiva Mission of Quebec: Montreal.

Simon, Gildas (2008) La planète migratoire dans la mondialisation, Paris: Armand Colin.

Soja, Edward (1989) Postmodern Geographies: The Reassertion of Space in Critical Social Theory, London: Verso.

Sooriamoorthy, Ramoo (1989) 'Temples over the Years', in S. Rajaram \& International Association of Tamil Research (eds.), Proceedings of the $7^{\text {th }}$ International Conference-Seminar of Tamil Studies, vol.1, Mauritius: Government Central Press, pp. 257-68.

Tarrius, Alain (1996) ‘Territoires circulatoires et espaces urbains', Annales de la recherche urbaine, 59-60, pp. 50-59.

Trouillet, Pierre-Yves (2010) Une géographie sociale et culturelle de l'hindouisme tamoule. Le culte de Murugan en Inde du sud et dans la diaspora, PhD Thesis, Bordeaux: University of Bordeaux, unpublished.

Vertovec, Steven (2000) The Hindu Diaspora. Comparative patterns, London: Routledge.

Wyatt, Andrew (2009) Party System Change in South India: Political Entrepreneurs, Patterns and Processes, Abingdon: Routledge.

\section{NOTES}

1. I thank Aurélie Varrel, Tristan Bruslé and the anonymous referees for their observations on the first draft of the paper.

2. From two temples per year in 1998 to nine per year in 2008 (personal enquiry). These numbers include the restoration of existing temples.

3. The transliteration of Tamil words is based on the system used by the Tamil Lexicon of the University of Madras.

4. In his illuminating article dealing with such places, the geographer Bernard Debarbieux (1993) notes that there is no English equivalent to the French expression 'haut lieu'; that is why the French term will be used in the following discussion.

5. In reference to the Tamil saying, 'kōvil illa uril kuți iruka vênțām' (do not live in a place with no temple).

6. http://www.thenseide.com/ulagathamizhar-eng/varalaru.htm.

7. This is illustrated by the motto printed on the flag of the organization, Yātum ūrē, yāvarum kēlir ('All places are our home, everyone our kin'), from a poem by Kaniyan Pungundranar. 
8. The Śaiva Mission preferred a more spacious location in the Montreal suburbs rather than a site in the middle of an urban setting in order to meet its objectives. (Saiva Mission of Quebec (2006) Thirumurugan Temple Montreal: Souvenir of the Consecration ceremony, Saiva Mission of Quebec: Montreal, 80 p.)

9. Saiva Mission of Quebec (not dated) Thiru Murugan Temple: Devotees Guide, Montreal, $10 \mathrm{p}$.

10. Weekly classes in the Tamil language and in the Śaiva religion formally commenced in 1996. Bharatanătyam and music classes started the year after, as well as activities at the temple library. 11. This deity has been present for a very long time in the Tamil pantheon and is recognized today as one of the two sons of the god Śiva. Murugan is also known as Subrahmanya, Skanda and Kārttikeya, particularly in North India.

12. In 2011, the Tamils represented $12 \%$ of Hindus in Mauritius and the Bhojpuri $80 \%$. The other Hindus on the island are Telugus (5\%) and Marathis (3\%) (Source: 2011 Census data, statistics Mauritius). Since independence in 1968, the post of Prime Minister has always been held by a member of the Bhojpuri community, except for the brief period from 2003 to 2005 where Paul Berenger, a member of the 'White' minority and of French origin, was the head of the State.

13. According to the 2006 Census, of about 300,000 Hindus living in Canada, one third are of Tamil origin (India and Sri Lanka) and two thirds come from North or West India. (Source: Statistics Canada. The 2011 Census data were not available at the time this article was written).

14. Regular interviews with activists from the Tamil Force by author, October 2008.

15. Names are fictitious.

16. Interviews conducted by author, Chennai, May 2007.

17. Interviews conducted by author, Mauritius, November 2008.

18. Interviews conducted by author, Paris, March 2011.

19. Famous city of Tamil Nadu, notably owing to its great temple dedicated to the goddess Mīnākșī.

20. For instance, a 'Palani of the north' (Vatapalani) was created at the end of the $19^{\text {th }}$ century near Madras and has given its name to a neighbourhood which is now within Chennai metropolitan area (Trouillet 2010). In North India, the Chār Dhām (Four Abodes) also have some replicas in different regions (Eck 1998).

21. Non-Resident Indians (NRIs) are Indian citizens holding an Indian passport and resident for an indeterminate period abroad, in practice all recent emigrants.

\section{ABSTRACTS}

Temples have been places of major importance for Tamil societies for more than fifteen centuries. Following the migration of Tamilians from South India, the perpetuation overseas of their tradition as temple builders and the creation of a Tamil diaspora, they can now be found on the five continents. They are indicative of the exportation of Tamil Hinduism on a global scale and prompt us to ponder the relationships linking these overseas temples and the Tamil migratory space. This paper examines the identity issues as well as the spatial meanings and transnational connections related to the making of such places. The study of some of these temples in Canada and Mauritius helps to determine how Tamil temples have become major centres of transnational social spaces and to document the geographical features of the building of 'hauts lieux' by migrant communities in host countries. 
INDEX

Keywords: Hinduism, temple, Tamil, migratory space, diaspora, haut lieu, Mauritius, Montreal, Tamil Nadu, Sri Lanka

\section{AUTHOR}

\section{PIERRE-YVES TROUILLET}

Research fellow, CNRS, Centre d'Etudes de l'Inde et de l'Asie du Sud, Paris 